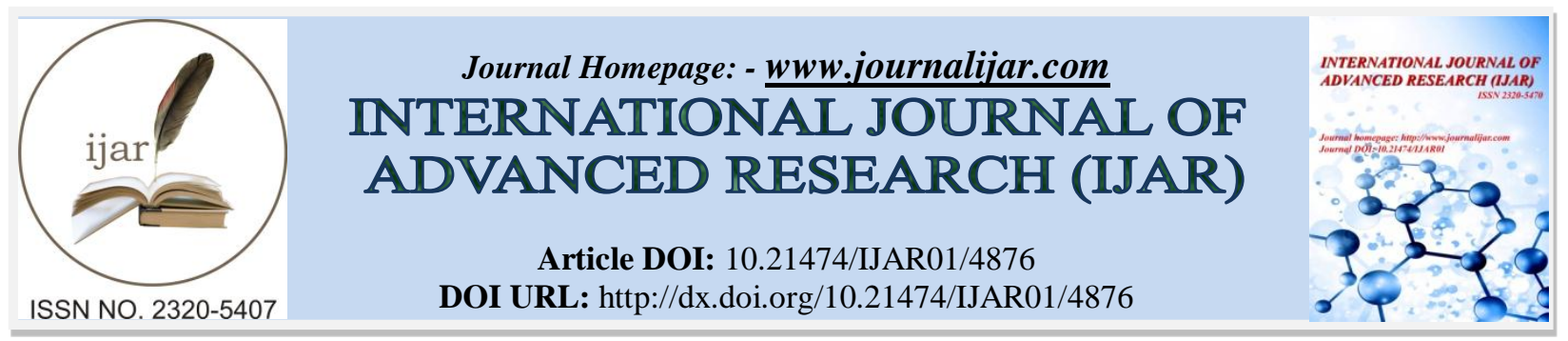

RESEARCH ARTICLE

\title{
UNDERSTANDING PUREESH VAHA SROTAS W.R.S. TO RECTUM: A LITERARY REVIEW.
}

Pankaj Rajvanshi.

Assistant Professor, PG Department of Rachna Sharir (Anatomy), H.A.M.C. \& H, Dehradun.

\section{Manuscript Info}

Manuscript History

Received: 18 May 2017

Final Accepted: 20 June 2017

Published: July 2017

\section{Abstract}

Mala represent the third member of the trinity of the living body. Purish is the faeces and it is also known as "vit" and "mala". It represents in part, the undigested residue left over after the nutrient fraction of thefood has been separated and absorbed. The study reviews the scattered literature on the Guda marma, pureesh waha srotas and related contemporary anatomy and physiology books for the anatomical and physiological understanding of rectum to provide their scientific evidences for considering pureesh waha srotas as Rectum. As per the review, one portion of rectum is used for the formation of purisha (pakvashaya) and other portion is used to help in defecation by receiving the defecation signals from rectum (sthool antra) to be used in initiation of defecation reflex (guda and sthoola guda) So it can be concluded that one portion of purishvaha srotas is involved in the formation of purish and other portion is involved in defecation process for the expulsion of flatus and faeces. Hence the present study can be used in understanding sroto viddha lakshana and other sroto dusthi symptoms and their management with reference to rectum.

Copy Right, IJAR, 2017,. All rights reserved.

\section{Introduction:-}

Mala represent the third member of the trinity of the living body, the other two members being the dosha and dhatu ${ }^{i}$. Word mala represent a wide variety of substances produced by the body, including tridosha and sapta dhatu in their abnormal states of functioning $\mathrm{ii}$.

Generally, mala are stated to comprise of shakrit (faeces), sweda (sweat), mutra (urine) etc. Two aspects of mala have been visualized viz, mala and kitia. The former represents waste products in general, of which some may be utilized by the body for its functional and structural purposes and other meant to be discarded. The kiita term has been derived from the root 'kitta gatau', meaning, "To go" and it generally refers to the waste products of the dhatus. Likewise the undigested residue or the asara of the lbw. Which is expelled out of the pakvashaya under the influence of apan vayzi through the three valis (fold) of the rectum is spoken of as the mala or purish or vit. ${ }^{3}$

Purish is the faeces and it is also known as "vit" and "mala". It represents in part, the undigested residue left over after the nutrient fraction of the-food has been separated and absorbed. ${ }^{\text {iii }}$ 


\section{Aim of Study:-}

This review aims at scanning the scattered literature on the Guda marma, pureesh waha srotas and related contomparory anatomy and phyiology books for the anatomical and physiological understanding of rectum to provide their scientific evidences for considering pureesh waha srotas as Rectum.

\section{Method:-}

Classical texts of Ayurveda as well as PUBMED, MEDLINE database were used for the search of relevant literature and research papers. Papers published between Jan 1960 to Jan 2015 were only considered. The key words used for the search was 'Ayurveda', 'Guda marma' 'pureesh waha srotas' 'Rectum' and 'excretory system' etc. Literary review, conceptual studies as well as anatomical books were included in the review along with classical texts and published contemporary books on Sharir kriya and rachna sharir were included. Only research articles published in English language were considered.

\section{Discussion:-}

The srota, which carry the purish, or faeces are called as "purish vaha srotas". The whole description related to purish vaha srotas till vedic period is given below:

Atharva Veda: The description of mala is present here as excreta of body. Other description of mala is present in reference to "rujayakshma roga" as mala is present in intestine. Large intestine is defined, as vanisthu. Guda and vanisthu

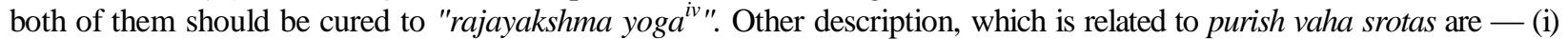
description of nadi of guda and antra's. (both large intestine and small intestine) ${ }^{\mathrm{v}}$; (ii) description of asthi which is present behind the guda ${ }^{v i}$; (iii) God of vanisthu (large intestine) is"era"vii, and God of guda is devajan ${ }^{\text {viii }}$ (iv) Guda is described as external aperture ${ }^{\mathrm{ix}}$. In Veda, the description of samara vayu and apan vayu is also present ${ }^{\mathrm{x}}$.

Shukla Yajurveda: In Shukla yajur Veda the process of digestion and dhatu poshana are related to the maha srotas, rasavaha srotas and rakta vaha srotas. In this description, the term anthra has defined as large intestine and small intestine. Guda and antra are the parts of maha srotas. ${ }^{\mathrm{xi}}$

Chandigaeoupanishad - The present description has pointed that after Digestion of ingested food, it is divided into three parts that is: (1) Purish （vistha); (2) Rasa etc. seven dhatus; (3) Small part for mana. Drunk water is divided into three parts that is: 1- Rakta, 2- Prana, 3-Mutra. ${ }^{\text {xii }}$ Subalaoupanishad - The present description has mentioned that main function of guda is viserjan, and it is joined to nadi (sthulantra ${ }^{\text {xiii }}$ Yogachudamaniupanishad - The present description has mentioned that Annan vayu is found in nabhi region and apan vayu is found in guda region ${ }^{\mathrm{xiv}}$. YogakundalupanishadAccording to this Upanishad in nabhi, manipur chakra is present and in Buda, muladhara chakra is located ${ }^{\mathrm{xv}}$. SharirioupanishadGuda is a karmandhrae and used only for expulsion function or viserjan karma of purish. Trishikhabrahmanoupanishad-Apan vayu is found in guda, uru, janu and medhu or penis region and its main function is to promote the outward motion of vayu, mutra, purish. Saman vayu is found in whole body and its main function is to promote the anabolic processes in the body. ${ }^{\text {xixixvii }}$

Guda is defined as $d w a r$, is one of in nine dwars of the body. It is defined here that with the help of apan vayu and prana, the agni (body heat) is activated which performs the digestion of four types of food.

Acharya Charak has explained the anatomy of purish vaha srotas in a light manner. He has mentioned that grahani and guda are situated in left side, due to this fact when lying on left side the enema should be reached easily and folds of guda do not interrupt the enemaxviii. The guda should be smeared with some uncting substance and also the nozzle, which should be introduced by its one fourth part slowly straight and parallel to the back, and then enema pouch should be pressed properly. Then enema is going up to umbilical region, waist, sides, and belly, stirring up the accumulated faeces and impurity and uncting the body, then it comes out with faeces and impurity properly. In this way by the route of vasti Acharya Charak has explained the anatomy of purish vaha srotas. Acharya Charak has described the regional anatomy of sthul guda. He has explained the position of sthul-guda in reference to position of vasti, which is situated in the middle of sthul guda, scrotum, raphe, vas deferens and ureters. It is mentioned by Chakrapani that vasti is situated on sthul guda. Acharya Charak has explained the guda as vital organ. Acharya Chakrapani has described the guda which contain two parts: oar guda is the part of guda where purish is found and adhar guda is the part of guda formed where purish is expelled out Acharya Charak has explained the pakvashaya, purishadhara (unduka - dalhana), sthul-antra, uttarguda and adhar-guda, are the organs which are maternal in origin. Acharya Charak has also mentioned these organs and purishaadhana as kosthang $^{\text {xix }}$ In respect of basic physiology of purish vaha srotas Acharya Charak has mentioned that, the prana vayu 
has function to carry the food to the belly where the food is disintegrated by fluid (juices) and softened by fatty substances, gets acted upon by the digestive fire fanned by the saman vayu. The digested fire cooks the timely taken and balanced food, properly leading to promotion of life span. Agni or digestive fire cooks the food and then divided it into rasa (nutrition fraction) and mala (excretion fraction). The food is composed of six rasas. Immediately after it is ingested, it undergoes the stage of prapaka firstly due to predominance of sweetness, madhur paka stage is found. Thereafter during the process of digestion when the food is half burnt and descending from stomach, due to predominance of acidity, amla paka stage is found. Lastly, when it reaches the pakvashaya, it is absorbed by fire and gets coverted into solid mass. Vayu (wind) is formed due to predominance of pungency. This stage of prapaka is called katupaka stage ${ }^{\mathrm{xx}}$. Acharya Charak has mentioned the saman vayu, as it is located in channel carrying sweat, $d o s h a$, water (fluid) and seated beside the digestive fire provides strength to "agni" ${ }^{\prime x x i}$. In respect of apan vayu, Charak has mentioned that it is found in testicle, urinary bladder, penis, navel, thigh's groins and its mains function is to promote outward motion of faeces, urine, semen, menses and fetus at their right time ${ }^{\text {xxii }}$.

In respect of suppression of defecation, he has explained the symptoms like colic pain, headache, retention of flatus and faeces, cramps in calf muscles, flatulence. Suppression of flatus causes retention of faeces, urine and flatus, flatulence, pain, exhaustion and other disorder in abdomen due to vata. ${ }^{\text {xxiii }}$

On account of symptom of purish kshya he has mentioned that when purish is present in fewer amounts then vayu is moving in the intestine, raising the abdomen and then it goes toward ribs area. In other words, excessive flatulence is $\operatorname{present}^{\text {xxiv }}$.

For clinical point of view Acharya Charak has explained the purish vaha srotamula are pakvashaya and sthul guda. The commentary of Gangadhar on purish vaha srotamula, mentioned that pakvashaya is situated below to umbilical region and sthul guda contain three folds. He also explained the characteristic of "pakvashaya" as it is the place where after digestion, the digested material enters and then the absorption of fluid from the residual or asara of digested matter takes place here which later on changes into solid form, called purish ${ }^{\mathrm{xxv}}$.

Acharya Charak has explained the symptoms of the morbidity of purish vaha srotas as: passing faeces with difficulty in small quantity with sound and pain, too liquid, too scabulous and evacuation of faeces in large quantity. In respect of purish vaha srotodusti nidan he has mentioned that holding up the urge for defaecation, over eating, eating during indigestion and while the previous meal is not digested, particularly in person with poor digestion-and lean and thin persons, are the main causative factors of purish vaha sroto dusii. On account of Anatomical consideration of purishvaha srotas, Sushrut has given some evidence like - The nabhi marma is present in between pakvashaya and amashaya. The "second evidence" is the purishdhara kala, which is found inside the Pakvashaya. The antra (Sthulantra), which contains purishdhara kala is near to liver and other organs. This maladhara kala specially absorbs the fluid from mala (purish) in unduka (Caecum) ${ }^{\mathrm{xxvi}}$.

Third evidence is the position of vata dosha which is found in pakvashaya and pakvashaya is situated in between, umbilical region and shronipradesh and guda. The fourth evidence is, the route of vasti which is given through guda. The vasti dravya ascends in kati, pakvashaya and situated below umbilical region ${ }^{\text {xxvii. }}$

Acharya Sushrut has described the guda as mamsa marm and said that it is connected to sthulantra. He has categorised the guda mann as sadhya pranhara marm and only function of guda is the expulsion of faeces and

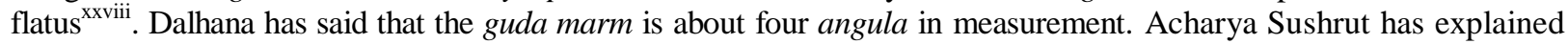
the development of different parts of purishvaha srotas. According to him, the unduka is formed from the kitta part of the blood and antra, guda of foetus develop from the essence of rak,ta and kapha digested by the pitta into which vayu enters. ${ }^{\text {xix }}$ Again, he has described, the unduka, antra, srotas, sira dhamni, marm, ashaya (pakvashaya) and yoga vahi srotas (purishvaha srotas) as, pratyanga ${ }^{x x}$. He has described the guda which is connected to sthul antra and it contain three folds ${ }^{\text {xxxi }} G u d a$ also contains three muscles. Acharya Sushrut has described the physiology of pakvashaya indirectly as the purishdhara kala is found in the pakvashaya whose main function is to absorb the fluid from faecal matter. In this way Acharya Sushrut has mentioned that pakvashaya is the place where faeces formation takes place ${ }^{\mathrm{xxxii}}$.

On the explanation of apan vayu, Sushrut has mentioned that the apan vayu acts in the lower region of the intestine (pakvashaya). Its main function is to promote downward motion of fetus, faeces, urine, semen and menstruation at their usual time $\mathrm{xxxiii}^{\mathrm{I}}$ 
According to Garnath Sen sthulantra or vrehadantra is divided into six parts that is: (1) Unduka or caecum; (2) ascending part; (3) transverse part; (4) descending part; (5) Kundalika or pelvic part, (6) Guda nalika or anorectum.

Gudadwar is the terminal part of adhar guda, situated in front of "anutrikusthi" and in between nitcunlm. This gudadwar is surrounded by external guda sankochini peshi (external anal sphincter). Venous plexus surrounds the guda nalika and it is the place of piles. Venous plexus characterizes its lower portion which is very sensitive to pain. In other words the adhar guda is the place where venous plexus is found and it is the site of pile, pain and sensitivity. Blood supply to sthul antra is performed by uttar antric (superior mesenteric) and adhar antric (inferior mesenteric) blood vessels.

The nerve supply of antra is formed by manipura chakra (coeliac plexus) and muladhara chakra (hypogastric plexus both superior and inferior). Both plexuses are responsible for the function of saman vayu (manipura chakra) and apan vayu (muladhara chakra). The guda pram is under control of men ${ }^{\mathrm{xxxiv}}$.

Garnath Sen has explained the pakvashaya as vrehadantra where maladhara kala is found. This purishdara kala is responsible for holding the faecal matter and also differentiates the faecal matter in the caecum (unduka). It is well known that the villi in the small intestine draw the juices of food and leave the residue, which enters the caecum as faeces ${ }^{\text {xxxv }}$

Ghanekar has mentioned the Pakvashaya as colon and commonly Pakvashaya term is taken in reference to Sthulantra (large intestine) ${ }^{\mathrm{xxxvi}}$

Ghanekar has mentioned that maladhara kala is situated in sthulantra which is near to the base of liver. Other organs are also near to it (spleen, Stomach, coil of small intestine, kidney) and two varchonirashana dhamani that are attached to large intestine are, inferior mesenteric artery, middle colic and right colic artery ${ }^{\text {xxvii }}$.

The word guda denotes a bit extensive Portion of the gut and is divided into two parts: Uttar guda - rectum, Adharguda - anal canal. Uttar guda is that portion where the excreta is lodged and adarguda is that through which it is expelled. The anal margin or lip, is the terminal portion of anal canal attached to the large intestine at its end lies "Guda" which is five and half angular long in this area seen three fold pravahani, visarjani and samvarani. The first of these three is $1 / 2$ angula above the anal lip. Guda is a seat of disease like piles, prolapus ani and fistula etc. ${ }^{\text {xxxviii }}$

According to ayurvedic kriya sharir, sthulantra has few parts that are: unduka or purishounduka (caecum), unduka-pucha (appendix), aarohi sthulantra (ascending colon), anuprastha sthulantra (transverse colon), avarohi sthulantra (descending colon), kundalika sthulantra (sigmoid colon). The above description is described, under heading of parts of pakvashaya. The last part of sthulantra is uttar guda. It is about 4 to 5 inches long, front of the uttar guda vasti and uterus is located, below uttar guda, shukrashaya, shukravahini, vastishir pourush granthi and yoni are found. The uttar guda opens into adhar guda. It is about 4 to 5 inch long. The whole adhar guda is surrounded by external gudostha (external sphincter) and internal gudostha (internal sphincter). The above description is described under heading of guda nalika in this book. The main function of sthulantra is to absorb fluid from faecal matter and then changed it into lump form is, called faeces or purish.

As per Commentary of Sushrut Samhita Sharir Sthana by Dr. Dinkar Govind Thatte: Faecal carriers are two in number. Their roots are, large intestine and rectum. Any injury to them may cause tympanitis, faecal or bad smell. This statement is very true because the stool is formed in the large intestine i.e. colon. The various parts included in the colon are caecum, ascending colon, hepatic flexure, transverse colon, and splenic flexure, descending colon, sigmoid colon and rectum. Symptoms allotted to the pathology of these anatomical segments of large intestine are all the same i.e. tympanitis, formation of fecolith and bad odour. In colitis excessive gas formation causes tympanitis.

\section{Conclusion:-}

On the basis of whole description of srotomula of purish vaha srotas, it can be explained as: one portion is used for the formation of purisha (pakvashaya) and other portion is used to help in defecation by receiving the defecation signals from rectum (sthool antra) to be used in initiation of defecation reflex (guda and sthoola guda) So it can be concluded that one portion of purishvaha srotas is involved in the formation of purish and other portion is involved 
in defaecation process for the expulsion of flatus and faeces. Hence the present study can be used in understanding sroto viddha lakshana and other sroto dusthi symptoms and their management with reference to rectum.

1. Sushruta : Sushruta Samhita, Part I with Ayurveda Tattva Sandipika Hindi Commentary, Edi. by Kaviraja Ambikadatta Shastri, Published by Chaukhambha Sanskrit Sansthan, Varanasi, 14th edition, 2003, Sutra Sthana $15 / 3$

2. Sharangadhara : Sharangadhara Samhita with Krishna Hindi Commentary, Edi. by Acharya Radhakrishna Parashar, Published by Sri Baidyanath Ayurved Bhavan Limited, Nagpur, 4th edition PU. KH 5/24

3. iiijVaghabhata : Astanga Sangraha Vol. I, with English Translation by Prof. K.R. Srikant Murthy, Published by Chaukhambha Orientalia, Varanasi, 1st edition, 1996, Sutra Sthana 1/31

4. Atharveda Ved Samhita, Bhag 1st edited by Ved Murti Taponishtha Pandit Sri Ram Acharya, Yug Nirmana Yojana,Gayatri Tapobhumi, Mathura (U.P), Reprint edition, 2005; 2/2/7/1; Pg: 477

5. Atharveda Ved Samhita, Bhag 1st edited by Ved Murti Taponishtha Pandit Sri Ram Acharya, Yug Nirmana Yojana,Gayatri Tapobhumi, Mathura (U.P), Reprint edition, 2005;10/5/9/16; Pg: 275

6. Atharveda Ved Samhita, Bhag 1st edited by Ved Murti Taponishtha Pandit Sri Ram Acharya, Yug Nirmana Yojana,Gayatri Tapobhumi, Mathura (U.P), Reprint edition, 2005; 9/4/14/17;Pg:102

7. Atharveda Ved Samhita, Bhag 1st edited by Ved Murti Taponishtha Pandit Sri Ram Acharya, Yug Nirmana Yojana,Gayatri Tapobhumi, Mathura (U.P), Reprint edition, 2005;9/4/1/12 Pg:94

8. Atharveda Ved Samhita, Bhag 1st edited by Ved Murti Taponishtha Pandit Sri Ram Acharya, Yug Nirmana Yojana,Gayatri Tapobhumi, Mathura (U.P), Reprint edition, 2005;9/4/1/12 Pg:95

9. Atharveda Ved Samhita, Bhag 1st edited by Ved Murti Taponishtha Pandit Sri Ram Acharya, Yug Nirmana Yojana,Gayatri Tapobhumi, Mathura (U.P), Reprint edition, 2005;10/1/2/31;Pg:163

10. Atharveda Ved Samhita, Bhag 1st edited by Ved Murti Taponishtha Pandit Sri Ram Acharya , Yug Nirmana Yojana,Gayatri Tapobhumi, Mathura (U.P), Reprint edition, 2005; 10/1/2/13;Pg:156

11. Yajurvediya kathopnishad-hindivigyanabhashya, Pt. Motilal Shashtri, Rajasthan Patrika Limited, Jaipur, first edition, January 1997; 19/86 (Page 500)

12. 108 Upanishada by Brahma Vidya khand edited by Pandit Shri Ram Sharma Acharya, Sanskriti Sansthan,Barielly, Reprint edition 4th,1969: 6/5/1;2;Gyan Khanda (page 297)

13. 108 Upanishada by Brahma Vidya khand edited by Pandit Shri Ram Sharma Acharya, Sanskriti Sansthan,Barielly, Reprint edition 4th,1969: 5 kanda1; Subalo upnishad (page 94)

14. 108 Upanishada by Brahma Vidya khand edited by Pandit Shri Ram Sharma Acharya, Sanskriti Sansthan,Barielly, Reprint edition 4th,1969: Yogchudamadi upnishad 23/24; pg:71

15. 108 Upanishada by Brahma Vidya khand edited by Pandit Shri Ram Sharma Acharya, Sanskriti Sansthan,Barielly, Reprint edition 4th,1969: Yogchudamadi upnishad 3/9, 10, 11; pg:271

16. 108 Upanishada by Brahma Vidya khand edited by Pandit Shri Ram Sharma Acharya, Sanskriti Sansthan,Barielly, Reprint edition 4th,1969: 79/80 Sadhna Khand (page 207)

17. 108 Upanishada by Brahma Vidya khand edited by Pandit Shri Ram Sharma Acharya, Sanskriti Sansthan,Barielly, Reprint edition 4th,1969: 83, 84,Sadhna Khand (page 202)

18. Agnivesha : Carakasamhita, Volume II with Caraka Chandrika, Hindi Translation by Brahmanand Tripathi, Published by Chaukhambha Sanskrit Prakashan, Varanasi, reprint 2004; Sidhi Sthan 3/24

19. Agnivesha : Carakasamhita, Volume II with Caraka Chandrika, Hindi Translation by Brahmanand Tripathi, Published by Chaukhambha Sanskrit Prakashan, Varanasi, reprint 2004; Shareer Sthan 7/10

20. Agnivesha : Carakasamhita, Volume II with Caraka Chandrika, Hindi Translation by Brahmanand Tripathi, Published by Chaukhambha Sanskrit Prakashan, Varanasi, reprint 2004; Chikitsa Sthan 15/6-11

21. Agnivesha : Carakasamhita, Volume II with Caraka Chandrika, Hindi Translation by Brahmanand Tripathi, Published by Chaukhambha Sanskrit Prakashan, Varanasi, reprint 2004; Chikitsa Sthan 28/9

22. Agnivesha : Carakasamhita, Volume II with Caraka Chandrika, Hindi Translation by Brahmanand Tripathi, Published by Chaukhambha Sanskrit Prakashan, Varanasi, reprint 2004; Chikitsa Sthan 28/10-11

23. Agnivesha : Carakasamhita, Volume II with Caraka Chandrika, Hindi Translation by Brahmanand Tripathi, Published by Chaukhambha Sanskrit Prakashan, Varanasi, reprint 2004; Sutra Sthan 7/12

24. Agnivesha : Carakasamhita, Volume II with Caraka Chandrika, Hindi Translation by Brahmanand Tripathi, Published by Chaukhambha Sanskrit Prakashan, Varanasi, reprint 2004; Sutra Sthan $17 @ 70$

25. Agnivesha : Carakasamhita, Volume II with Caraka Chandrika, Hindi Translation by Brahmanand Tripathi, Published by Chaukhambha Sanskrit Prakashan, Varanasi, reprint 2004; Sharir Sthan $7 @ 7$ 
26. Sushruta : Sushruta Samhita, Part I with Ayurveda Tattva Sandipika Hindi Commentary, Edi. by Kaviraja Ambikadatta Shastri, Published by Chaukhambha Sanskrit Sansthan, Varanasi, 14th edition, 2003, Sutra Sthana $21 / 6$

27. Sushruta : Sushruta Samhita, Part I with Ayurveda Tattva Sandipika Hindi Commentary, Edi. by Kaviraja Ambikadatta Shastri, Published by Chaukhambha Sanskrit Sansthan, Varanasi, 14th edition, 2003, Chikitsa Sthana35/24

28. Sushruta : Sushruta Samhita, Part I with Ayurveda Tattva Sandipika Hindi Commentary, Edi. by Kaviraja Ambikadatta Shastri, Published by Chaukhambha Sanskrit Sansthan, Varanasi, 14th edition, 2003, Sharira Sthana $6 / 26$

29. Sushruta : Sushruta Samhita, Part I with Ayurveda Tattva Sandipika Hindi Commentary, Edi. by Kaviraja Ambikadatta Shastri, Published by Chaukhambha Sanskrit Sansthan, Varanasi, 14th edition, 2003, Sharira Sthana $4 / 25$

30. Sushruta : Sushruta Samhita, Part I with Ayurveda Tattva Sandipika Hindi Commentary, Edi. by Kaviraja Ambikadatta Shastri, Published by Chaukhambha Sanskrit Sansthan, Varanasi, 14th edition, 2003, Nidana Sthana $3 / 5$

31. Sushruta : Sushruta Samhita, Part I with Ayurveda Tattva Sandipika Hindi Commentary, Edi. by Kaviraja Ambikadatta Shastri, Published by Chaukhambha Sanskrit Sansthan, Varanasi, 14th edition, 2003, Nidana Sthana $2 / 5$

32. Sushruta : Sushruta Samhita, Part I with Ayurveda Tattva Sandipika Hindi Commentary, Edi. by Kaviraja Ambikadatta Shastri, Published by Chaukhambha Sanskrit Sansthan, Varanasi, 14th edition, 2003, Sharira Sthana $4 / 16$

33. Sushruta : Sushruta Samhita, Part I with Ayurveda Tattva Sandipika Hindi Commentary, Edi. by Kaviraja Ambikadatta Shastri, Published by Chaukhambha Sanskrit Sansthan, Varanasi, 14th edition, 2003, Nidana Sthana $1 / 19$

34. Gananath Sen: Sharir Paribhasha; Kalpataru Press Calcutta; Pratyakhsa Shariram Aashya Khand: Pg 210-216

35. Gananath Sen: Sharir Paribhasha; Kalpataru Press Calcutta; Sangya Panchak Vimarsha

36. Sushruta : Sushruta Samhita, Part I with Ayurveda Tattva Sandipika Hindi Commentary, Edi. by Kaviraja Ambikadatta Shastri, Published by Chaukhambha Sanskrit Sansthan, Varanasi, 14th edition, 2003, Sharira Sthana 5/7: Ghanekar ommentary

37. A.F.Golwalla. Medicine for Student. Jaypee Public $22^{\text {nd }}$ edition. Pg. 64

38. Textbook of pathology. By William Boyd, M.D., F.R.S., Professor Emeritus of Pathology, University of Toronto. Seventh edition 